\title{
Florida's Introduced Birds: House Finch (Carpodacus mexicanus) 1
}

\section{Steve A. Johnson and Jill Sox ${ }^{2}$}

A wide variety of non-native birds have been introduced in Florida-perhaps as many as 200 species! Of these, at least 14 introduced species are considered established, according to various authorities, and some are now considered invasive and could have serious impacts in Florida. This fact sheet introduces the House Finch, and is one of a series of fact sheets about Florida's established non-native birds and their impacts on our native ecosystems, economy, and the quality of life of Floridians. For more information on Florida's introduced birds, how they got here, and the problems they cause, read "Florida's Introduced Birds: An Overview" (http://edis.ifas.ufl.edu/UW297) and the other fact sheets in this series, http://edis.ifas.ufl.edu/ topic_series_floridas_introduced_birds.

\section{Species Description}

The House Finch (Carpodacus mexicanus) is a member of the finch family (Fringillidae), which are small, seed-eating songbirds. These sparrow-like birds are common visitors to backyard bird feeders. Adult House Finches are 5-6 inches $(13-14 \mathrm{~cm})$

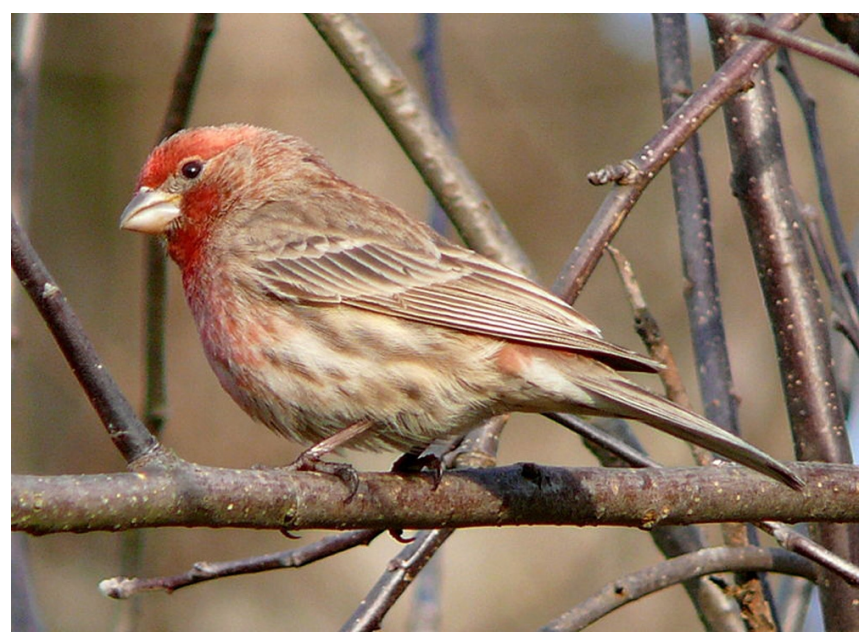

Figure 1. Male House Finch (Carpodacus mexicanus) Credits: Ken Thomas

long with a wingspan of $8-10$ inches $(20-25 \mathrm{~cm})$ and weigh approximately 1 ounce $(25 \mathrm{~g})$. Both males and females have brown back and wing feathers with dark streaks and white tips, and their belly or underside is white and heavily streaked with brown. House Finches have black eyes, dark brown legs, and a short, brown beak with an arched top edge. The male (Fig. 1) is characterized by bright red/orange or yellow color around his eye and on his neck, upper

1. This document is WEC 253, of the Department of Wildlife Ecology and Conservation, University of Florida / IFAS. This document is the first of several documents in the series entitled "Florida's Introduced Birds," published by Dr. Steve A. Johnson. Visit the University of Florida's EDIS website at http://edis.ifas.ufl.edu. First published March 2009.

2. Steve A. Johnson, assistant professor and Extension specialist, Department of Wildlife Ecology and Conservation and Gulf Coast Research and Education Center, University of Florida/ IFAS - Plant City Center, 1200 North Park Road, Plant City, FL 33563; Jill Sox, student, Gulf Coast Research and Education Center, University of Florida/ IFAS - Plant City Center, 1200 North Park Road, Plant City, FL 33563.

The Institute of Food and Agricultural Sciences (IFAS) is an Equal Opportunity Institution authorized to provide research, educational information and other services only to individuals and institutions that function with non-discrimination with respect to race, creed, color, religion, age, disability, sex, sexual orientation, marital status, national origin, political opinions or affiliations. U.S. Department of Agriculture, Cooperative Extension Service, University of Florida, IFAS, Florida A. \& M. University Cooperative Extension Program, and Boards of County Commissioners Cooperating. Millie Ferrer-Chancy, Interim Dean 


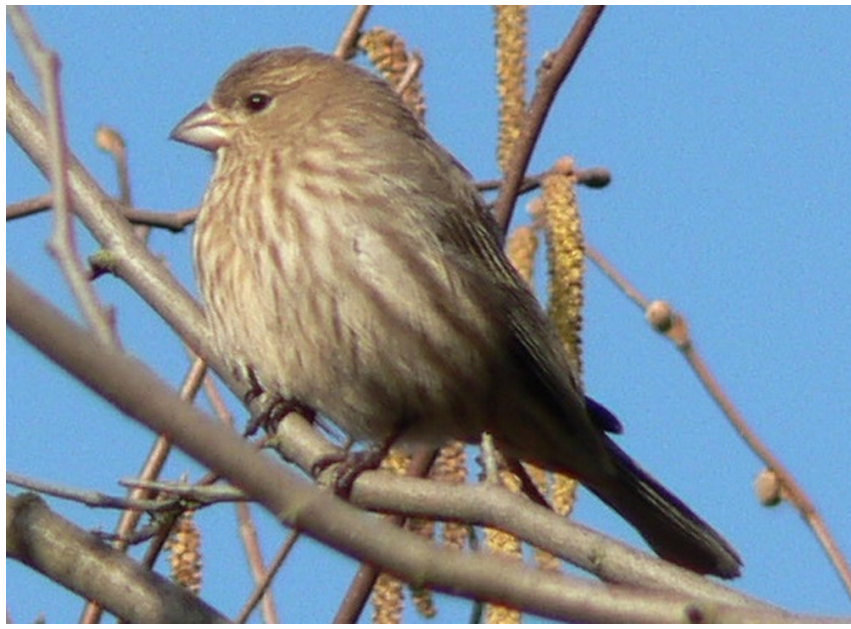

Figure 2. Female House Finch (Carpodacus mexicanus) Credits: Walter Siegmund

chest, and rump. During the late summer, the male molts completely, replacing all of his body feathers. During this period, the male eats brightly colored foods (such as red berries and flower buds) that will determine how brightly colored his new feathers will be. In contrast, the female (Fig. 2) has a solid brown head and lacks red markings. Juvenile House Finches are similar in appearance to the females but lack white bars on their wings. The song of the House Finch is a high-pitched, warbling "chee-er!"

\section{Similar Species}

The House Finch and Purple Finch (Carpodacus purpureus) are very similar in size and color and are easily confused. However, male Purple Finches are larger, and the bright red coloring is much more extensive, covering their entire head, back, wings, and chest (which lacks streaks). Female Purple Finches, like female House Finches, are drab in color but have distinctive white lines above their eyes. The Purple Finch winters as far south as northern Florida, but primarily lives in the northeastern United States and Canada. The range of the House Finch in Florida is significantly larger, and this species is a year round resident in Florida - if they do migrate seasonally, it is only for a short distance.

\section{Native Range and Habitats}

House Finches are native to the southwestern United States west of the Rocky Mountains and to Mexico. They thrive in a variety of habitats wherever seeds are abundant, including forests, deserts, grasslands, savannas, urban areas, and agricultural lands.

\section{Mode of Introduction}

In the 1930s, native southwestern House Finches were marketed by the pet trade as "Hollywood Finches" and sold in New York City. When the practice of selling wild songbirds became illegal in 1940, some irresponsible pet dealers released a few captive House Finches on Long Island in order to avoid prosecution. The small population struggled for survival for many years, but by the 1950s had become established among the urban buildings in New York City. The range of the House Finch rapidly expanded from there,likely due to attempts to attract these birds to backyard bird feeders.

\section{Introduced Range and Habitats}

House Finches are now seen in most areas of the contiguous United States (Fig. 3), and have been reported in 31 Florida counties. They are fully established in the northern portions of the state, with breeding populations present for at least ten years. The eastern population of introduced House Finches has expanded westward to reach the Rocky Mountains, which mark the eastern extent of the historical range of the southwestern population of native birds. Many experts believe that the native and introduced populations are now continuous. This species is present seasonally in central and southern regions. House Finches inhabit populated areas, including urban, suburban, and small town environments, and are usually sighted at backyard bird feeders.

\section{Ecology}

The diet of House Finches is highly varied - they will eat almost any type of seed and many fruits, grains, flowers and buds. In urban areas, they frequent backyard feeders and forage for seeds and fruits in home landscapes and gardens. During the fall and winter, adults and young birds in a localized geographic area will join together and forage as a flock. These large flocks of House Finches cause damage to many fruit and vegetable crops, including apples, apricots, avocados, blackberries, cherries, 


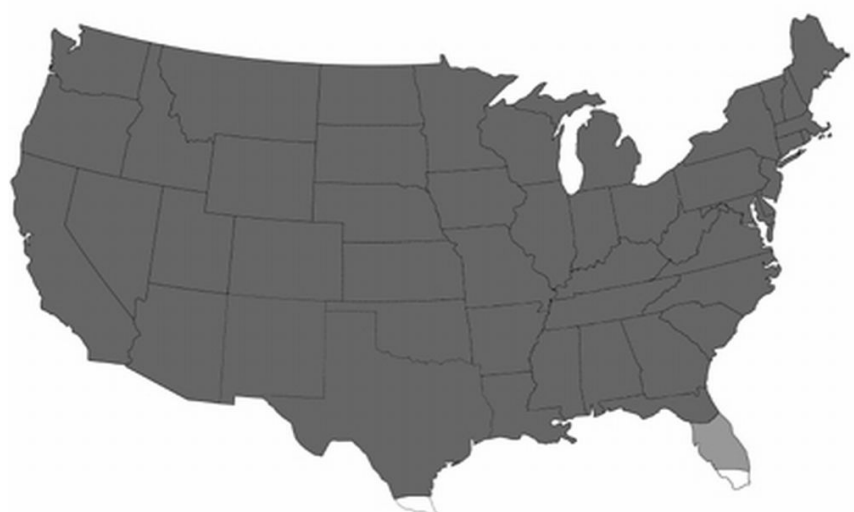

Figure 3. United States range of the House Finch (Carpodacus mexicanus)-year-round range shown in dark gray, seasonal range shown in light gray. Introduced populations in the East are believed to have merged with native populations to the west of the Rocky Mountains (shown in black). Credits: Monica McGarrity

figs, grapes, nectarines, peaches, pears, plums, prunes, raspberries, and strawberries.

Mating begins in late winter or early spring, allowing most House Finches to breed twice during the season. When choosing a mate, females select the male with the brightest red feathers of all the available males. Since the coloring comes from the finch's diet, experts believe that a female perceives the most colorful males as being the most capable of providing food for her and her young. Female House Finches build a small, cup-shaped nest in a sheltered location out of any available fine material, such as grass or string. Window ledges, tree hollows, birdhouses, shrubs and undisturbed piles of debris are all satisfactory nesting sites. Females lay 3-6 small, pale blue eggs with black flecks on the larger end (Fig. 4). The female incubates the eggs, relying on the male to provide her with food during this period. The young hatch in 12-14 days and leave the nest 11-19 days later.

\section{Ecological Impacts}

In recent years, introduced House Finches have experienced an epidemic of House Finch Conjunctivitis, a disease caused by parasitic bacteria. Although there is no direct risk to humans, this disease can spread to some native bird species as well as to poultry. Symptoms of conjunctivitis include irritated, swollen, crusty, or runny eyes. If severe, the disease may result in blindness, and the bird will be

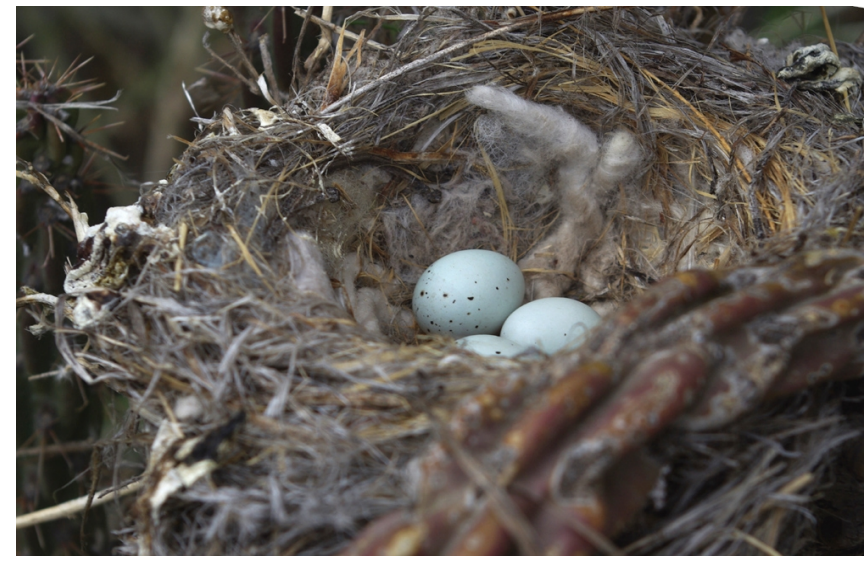

Figure 4. House finch (Carpodacus mexicanus) eggs. Credits: Jerry Friedman

unable to feed and will starve to death. This condition was first noted in finches near chicken farms in the Washington, D.C. area during the unusually harsh winter of 1994; by 1996, 37\% of observed House Finches showed symptoms. The introduced eastern population of House Finches descended from only a few released birds. Experts believe that the combination of disease and reduced genetic diversity of the introduced population caused the deaths of half of this population during the peak outbreak. Currently, only an estimated 5-10\% of the eastern introduced finch population is infected with conjunctivitis.

However, there is a risk that conjunctivitis could be spread to other native bird species in Florida, causing a decline in their numbers.

House Finches are known to compete with native birds for nest cavities, a critical resource that has already been severely reduced by loss of natural habitats to urbanization. House Finches also compete for nest boxes installed to benefit native birds. There is some evidence to suggest that these fierce competitors may even be contributing to the decline of another non-native bird in Florida, the House Sparrow.

\section{Impacts to People and Pets}

Many birdwatchers enjoy the beauty and song of the House Finch and do not consider them to be a nuisance. However, large foraging flocks could cause extensive damage to the state's fruit, vegetable and ornamental plant industries as well as to home 
gardens. Given the males' preference for red fruit, strawberry and tomato crops could be affected. If House Finches spread conjunctivitis to poultry, the poultry industry could suffer losses as well.

\section{Solutions}

There are several ways to minimize damage from House Finches. Cover fruit-bearing plants such as strawberries with plastic netting $(1 / 2 \mathrm{inch} / 1.25 \mathrm{~cm}$ mesh). This method can be costly, but it provides an effective physical barrier from foraging birds. Eliminate potential nesting sites by removing trash, stacks of pipes, debris, and wood and by keeping shrubs trimmed. Loud noises like clattering pie pans and physical deterrents like scarecrows are usually not effective. Capsicum (red pepper) repellents may be used to manage certain crops to prevent finch damage, but should be used with care. Australian crow traps can be modified to catch House Finches. More information on this method can be found on the website of the Internet Center for Wildlife Damage and Management (http://icwdm.org).

If you suspect a bird is infected with conjunctivitis, report it to the House Finch Disease Survey (http://www.birds.cornell.edu/hofi). Clean bird feeders frequently (and after sighting infected finches) with a solution of 1 part bleach to 9 parts water, and rake up and disperse bird droppings and old birdseed that accumulate below the feeder.

\section{How You Can Help}

You can help to alleviate the growing numbers of non-native bird species in Florida by being a responsible and educated pet owner. Never set any pet free outside! You can also help by learning more about invasive plants and animals and their impacts on Florida's natural environment, and by educating others. For more information on Florida's introduced birds and how you can help, read "Florida's Introduced Birds: An Overview" (http://edis.ifas.ufl.edu/uw297), and check out the Additional Resources listed below.

\section{Additional Resources}

We recommend several different online guides, books and other publications that provide additional information on Florida's native and non-native birds.

\section{Books and Scientific Publications}

Avery, M. L., and M. P. Moulton, "Florida's non-native avifauna," Managing Vertebrate Invasive Species: Proceedings of an International Symposium (G. W. Witmer, W. C. Pitt, K. A. Fagerstone, Eds.). (Fort Collins, CO: USDA/APHIS/WS, National Wildlife Research Center, 2007).

Alsop, Fred J., Smithsonian Handbooks: Birds of North America - Eastern Region. (New York: DK Publishing, Inc., 2001).

Bull, J., and J. Farrand, Jr., The Audubon Society Field Guide to North American Birds. (New York: Alfred A. Knopf, 1977).

Kale, H. W. II, and D. S. Maehr, Florida's Birds. (Sarasota: Pineapple Press, Inc., 1990).

Peterson, R. T., Peterson Field Guides, Eastern Birds. (Boston: Houghton Mifflin Co., 1980).

Pranty, B., A Birder's Guide to Florida. (Colorado Springs: American Birding Association, 1996).

Robbins, C. S., B. Bruun, H. S. Zim, and A. Singer, A Golden Guide to Field Identification:

Birds of North America. (New York: Golden Press, 1983).

Sibley, D. A., The Sibley Field Guide to Birds of Eastern North America. (New York: Knopf, 2003).

Woolfenden, G. E., W. B. Robertson, Jr., and J. A. Cox, The Breeding Birds of Florida. (Florida Ornithological Society Special Publication 7, 2006)

\section{Online}

USDA National Invasive Species Information Center (NISIC) http://www.invasivespeciesinfo.gov/index.shtml

Florida Fish and Wildlife Conservation Commission Non-Native Wildlife 
http://www.myfwc.com/

WILDLIFEHABITATS/Nonnative_index.htm

— click on "Birds"

Florida Fish and Wildlife Conservation Commission

Breeding Bird Atlas

http://myfwc.com/bba/default.htm

World Conservation Union, Species Survival Group, Invasive Species Specialist Group http://www.issg.org — click on "Global Invasive Species Database," search for species

Cornell Lab of Ornithology "All About Birds" http://www.allaboutbirds.org/—click on "Bird Guide," search for species

United States Geological Survey, Patuxent Wildlife Research Center, Bird Identification http://www.mbr-pwrc.usgs.gov—click on "Bird Identification InfoCenter"

Cornell Lab of Ornithology "House Finch Disease

Survey" http://www.birds.cornell.edu/hofi

Internet Center for Wildlife Damage Management Finch Control

http://www.icwdm.org/handbook/birds/

HouseFinches.asp

Center for Disease Control and Prevention, National Center for Infectious Diseases, "Mycoplasmal Conjunctivitis in Wild Songbirds: The Spread of a New Contagious Disease In A Mobile Host Population" http://www.cdc.gov/ncidod/eid/vol3no1/fischer2.htm 